\title{
Research on Sub-Saharan Africa's Unrecorded International Trade: Some Methodological and Conceptual Problems
}

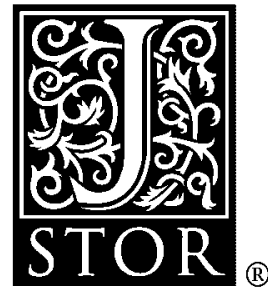

\author{
Stephen Ellis; Janet MacGaffey \\ African Studies Review, Vol. 39, No. 2. (Sep., 1996), pp. 19-41.
}

Stable URL:

http://links.jstor.org/sici?sici=0002-0206\%28199609\%2939\%3A2\%3C19\%3AROSAUI\%3E2.0.CO\%3B2-S

African Studies Review is currently published by African Studies Association.

Your use of the JSTOR archive indicates your acceptance of JSTOR's Terms and Conditions of Use, available at http://www.jstor.org/about/terms.html. JSTOR's Terms and Conditions of Use provides, in part, that unless you have obtained prior permission, you may not download an entire issue of a journal or multiple copies of articles, and you may use content in the JSTOR archive only for your personal, non-commercial use.

Please contact the publisher regarding any further use of this work. Publisher contact information may be obtained at http://www.jstor.org/journals/afsta.html.

Each copy of any part of a JSTOR transmission must contain the same copyright notice that appears on the screen or printed page of such transmission.

JSTOR is an independent not-for-profit organization dedicated to creating and preserving a digital archive of scholarly journals. For more information regarding JSTOR, please contact support@ jstor.org. 


\section{Research On Sub-Saharan Africa's Unrecorded International Trade: Some Methodological and Conceptual Problems*}

\section{Stephen Ellis and Janet MacGaffey}

The New Directions Papers is a new series of the Joint Committee on African Studies (JCAS) of the American Council of Learned Societies (ACLS) and the Social Science Research Council (SSRC). The purpose of New Directions is to open or re-open a field of African studies which has been neglected or in which not enough new work has been done. Thus, it is intended as a forum for challenging rather than surveying research agendas and received wisdoms that have shaped understandings about Africa. The Committee seeks papers that are empirically-based but methodologically- or theoretically-minded. For example, a case study would be viewed as an opportunity to show how a new perspective on African realities can be achieved through an innovative approach. In general, the Committee favors papers that can help colleagues who work in Africa to renew their practice of the field. The series will appear jointly in the African Studies Review and Cahiers d'etudes africaines, published simultaneously in English and French.

This paper is an attempt to describe some of the methodological and conceptual problems in researching aspects of sub-Saharan Africa's international "underground" trade, meaning commercial transactions which are conducted across international frontiers but which are unrecorded in official data. We focus particularly on trade across intercontinental frontiers. Trade may go unrecorded for a great variety of reasons: small-scale operators may believe, rightly or wrongly, that the degree of official contact necessary to record a transaction will involve them in some unwanted expense, in the form of time-consuming paperwork, payment of customs-dues or other taxes and possibly of bribes. The larger-scale operators, enjoying a high degree of political "protection" or even being holders of public office themselves, may enjoy an effective exemption from taxes and other charges in the countries where they are based.

Informal economic activity, by its nature, is difficult to detect and to measure, whether in Africa or anywhere else (Tanzi 1982; Alessandrini and Dallago 1987; Thomas 1992). The trade we are 
describing is part of what is variously referred to as the "second," "hidden," "parallel," "underground" and "informal" economy, all terms intended to convey the sense of economic activity which is not officially reported to state authorities and which is therefore not directly taxable. Although such activities are not necessarily illegal, they may involve a wide range of degrees of illegality.

The small-scale enterprises of the urban poor in particular, which make up an important part of the informal sector, have been the subject of frequent studies (Hugon and Deblé 1982; Penouil and Lachaud 1985). Far less research has been done on the various forms of exchange which are also part of the informal economy. For present purposes we propose to examine unofficial trans-frontier trade, particularly that which joins Africa to other continents, rather than production or any other branch of economic activity. A great variety of commodities are involved in underground economic exchange. One major category, both within and between African countries, and both to and from other continents, is foodstuffs. Food crops move between African countries and are exported to African communities in European cities. Canned and processed foods travel the same routes. Spices, fish, ivory, hides and skins are exported in East Africa especially, sometimes clandestinely. Cattle move in huge numbers on the hoof across African borders. Some export crops, such as coffee, tea and papaine, may be fraudulently exported or smuggled. Minerals are major commodities in clandestine export, notably gold, diamonds and other gemstones, malachite and cobalt. The transit trade in drugs from Latin America and the Far East is increasing.

While some commodities move out of Africa, manufactured products are imported. These include pharmaceuticals, construction materials, vehicles (new, second-hand and stolen), fuel, spare parts, soap, household goods and electrical appliances, electronic goods, office equipment, cigarettes and alcoholic drinks. These come increasingly from Asia, particularly via Dubai. Clothes, new and second-hand (known as friperies), shoes, jewelry and other accessories are imported from Europe, as are beauty products from the Caribbean, the USA and Europe. Cloth (especially wax prints) is imported from Europe and China and exported to other regions of Africa from West Africa, and is the basis of an extremely lucrative trade largely controlled by women.

In the following pages we will consider some problems of identifying and researching long-distance trade, and particularly inter-continental trade, which is illegal, unofficial or informal. We will do so at two levels: first, by looking at sources of evidence for intercontinental flows; second, by adopting a "bottom-up" approach, studying the activities of individuals or small groups of intercontinental traders with a view to extrapolating from their activities 
in order to draw conclusions of wider application. Finally, we will make some remarks concerning new modes of unofficial trade and the people who participate in them.

\section{Methodological Issues}

In contemplating the macro aspects of informal trade, we might usefully begin with a distinction between trade which is wholly or partially legal and that which is wholly illegal. Of the trades listed above, many are not illicit or illegal by nature but traders may seek to conceal their movements as a means of gaining a commercial advantage. A corollary of this is that such transactions are likely to escape registration in most sets of official figures.

In order to explore some of the methodological problems concerned, we will take two examples. The first is that of the ivory trade, which was unrestricted until 1989 in some countries, but restricted in others, so that ivory was widely smuggled. ${ }^{1}$ A second example, of a trade illegal everywhere, is that provided by the trade in cocaine, heroin and other narcotics.

\section{The Macro-Level: The Inter-Continental Trade in Ivory and Drugs}

The ivory trade is one of the oldest branches of long-distance commerce known in Africa. Ivory has traditionally been exported as a luxury product to consumers outside the continent, and the fact that ivory has always had a high international value relative to its bulk has made it, like gold and gemstones, a commodity which is sometimes held by traders as a form of cash. The pioneering work on the modern trade was done by a former game warden and ivory-trader, Ian Parker. ${ }^{2}$ In tracing Kenyan ivory exports from 1950 to 1977, Parker was able to use statistics published by the Kenyan government in respect to Customs and Excise returns. However, when these were compared with import statistics published by non-African consumer countries, there were a number of substantial and obvious anomalies. For example, in the case of Hong Kong-Kenya's main ivory export market-import figures for 1970-1977 compiled by the Hong Kong customs, when compared with the Kenyan export figures, suggested that real Kenyan ivory exports to Hong Kong were no less than 137 percent greater than those acknowledged by the Kenyan authorities (Parker and Amin 1983, 86). As Parker points out, it is wrong to assume that this discrepancy represents ivory illegally exported from Kenya and therefore unreported. Rather, the discrepancy was partly explicable by changes in the manner in which statistics were gathered in Kenya and the ways in which different forms of ivory-hunting or ivory-collecting licenses were attributed. Nevertheless, the under-reporting of Kenyan ivory exports certainly concealed a considerable degree of poaching in Kenya. 
Senior political figures in Kenya had interests in the trade. Some of the ivory imported to Hong Kong was later re-exported to Japan, where it was registered as ivory of Kenyan origin, creating a risk of doublecounting for anyone seeking to use import statistics as a means of calculating total Kenyan exports (Barbier, Burgess, Swanson, and Pearce 1990, 45-46). However, with suitable care to make allowance for such factors as these, it was possible to use figures for Hong Kong and Japanese imports to calculate the true level of Kenyan ivory exports and, indeed, the rate at which elephants were being killed.

Another source of figures on the African ivory trade is the Convention on International Trade in Endangered Species of Flora and Fauna (CITES), established in 1975 as an international system for control of the trade in animal products, including ivory. Its secretariat is in Switzerland. At first, adherence to the CITES treaty was entirely voluntary on the part of states, and it had little effect in restricting the trade in ivory. A new arrangement was eventually agreed to by the various member-states at a CITES meeting in 1985 and was implemented the following year. The new system required signatories to the Convention to adopt national ceilings, representing maximum figures for the quantity of ivory which they expected or hoped to trade in the following year. These ceilings were to be fixed after discussion with the CITES secretariat, and all other parties to the Convention would be notified of the limits. Importing countries were to agree that they would not import goods from any ivory-producing country that exceeded its limit. Although this mechanism has often been described as a quota system, properly speaking it did not involve ascribed quotas but required signatories only to notify the CITES secretariat of the trade ceilings which they themselves were proposing. This system, like its predecessor, was weak, since exporting countries were free to set their own limits and there was no international agreement on what overall volume of ivory should be traded annually in the whole world. Traders had every incentive to trade illegally acquired ivory by using false certificates, or genuine ones which they had obtained by bribery or other means. National governments were tempted to manipulate the figures to hide the real level of their imports and exports. One of the by-products of the new system, therefore, was to make it considerably harder to compile accurate statistics on the ivory trade, already a difficult enough task. As various ivory-producing countries joined CITES, placing a ceiling on their legal exports, traders wishing to bypass official controls could simply smuggle ivory to a neighboring country which had not adhered to the Convention and thus export ivory legally. The country which benefited most immediately from this provision in the mid-1980s was Burundi, where no elephants lived but which became a major exporter of ivory, most of it originating in Kenya, Tanzania and Zaïre. Hence, while official Burundian ivory export 
figures of the period tell us nothing about Burundi's own elephant population (since it didn't have one), they do tell us a good deal about the dynamics of the regional cross-frontier ivory trade. CITES statistics, treacherous though they may be, can be used to study the international movement of this semi-legal commodity at least until 1989 , when CITES banned all trade in ivory, making such trade illegal in all signatory states (Barbier, Burgess, Swanson, and Pearce 1990, 6-7; Douglas-Hamilton and Douglas-Hamilton 1992, 296-302). Until this point, CITES figures as well as other national statistics could be used to study ivory trade movements. ${ }^{3}$

A similar method could be used for any commodity which is legally traded in at least part of the series of transactions which combine to make an international trade. For example, CongoBrazzaville produces no diamonds of its own, yet reports considerable export of them: these figures can reveal the scale and routes of diamond smuggling from neighboring Zaire (Dupriez 1968, 682). Similarly, the estimated gold production of Zaïre for 1989 given in the publication The Consolidated Gold Field, is 12.1 tonnes, although the yearbook of the Zaïrian Centre National d'Expertise (CNE) records only 3 tonnes. However, the latter also gives the annual gold production for 1989 of Burundi, Zaïre's eastern neighbor adjacent to the gold fields, as 16 kilos, although the cargo manifest of the airline Sabena shows 533.9 kilos were exported from Bujumbura in the months of February and March 1989 ALONE. Gold was simultaneously exported from Zaïre to Sudan, Kenya, Uganda, Rwanda and Tanzania (Le Potentiel, 8 March 1993). Another Kinshasa newspaper reports unofficial gold exports on a similar scale in each case in 1993, to Burundi, Sudan, Kenya, Uganda and Rwanda (La Semaine, 17-19 February 1993).

Since 1989, the total ban on the ivory trade has put ivory in the same category as illegal drugs, notably cocaine and heroin, from the point of view of the analyst in search of data. Anecdotal evidence in the form of newspaper reports, as well as the records of judicial proceedings taken against drug smugglers arrested in the principal consumer markets of North America and Europe and other official sources, suggest that the African role in the narcotics trade is now quite considerable (Cesoni 1992). Leading agencies which publish relevant figures include the US Drug Enforcement Agency, the US State Department, the United Nations and Interpol.4 Reference to such sources suggests strongly that citizens of some African countries, and Nigeria in particular, have assumed the role of leading middlemen in the international drug trade, buying cocaine and heroin in South America or South-East Asia and ensuring its transport to the consumer markets of the North. Scrutiny of the estimates produced by the various agencies, in combination with judicial records and other sources, 
can permit at least the beginnings of a picture of Africa's involvement in this high-value international trade.

Data in regard to other economic activities, moreover, may help to verify these calculations and to shed light on the context in which the trade occurs. In West Africa especially, international traders of all descriptions-whether dealing in legal, illegal, formal or informal sectors-have sought to convert their profits into CFA francs, the hard currency of the region, in order to benefit from a source of foreign exchange which is negotiable internationally. Indeed, so great has been this tendency that the conversion of profits into CFA by Nigerian traders especially, including by illegal exchange of naira for CFA and the export of the latter to European bank accounts, was one of the main factors causing the devaluation of the CFA franc in January 1994. An exporter from Nigeria, with its "soft" naira, frequently would want to transfer his or her profits into the harder CFA, if necessary illegally. The statistics published by the CFA monetary authorities thus help to throw light on the international transfer of commodities which do not appear in reliable customs figures, including the drug trade.

\section{The Micro-Level: Research on the Traders}

The large picture which can be drawn of international trade movements using such sources as these needs to be supplemented by evidence drawn from a micro-level: by the detailed observation of techniques used by small groups of traders and by individuals. It is extremely difficult to persuade people to give details of the clandestine trading activities they practice; research on individual traders thus poses a considerable methodological challenge. This section of the paper focuses on how researchers have met this challenge, particularly in investigating how traders organize their trade, how they get into it, what is traded, by whom and why and how profitable it is.

People involved in unrecorded economic exchanges are wary of discussing what they do in direct relation to the intensity of the reaction of the authorities to their activities. The researcher's primary problem is to find ways to get informants' trust. The difficulty of this process will depend in part on the degree of illegality of the commodities being exchanged, on local politics, on state policies and their implementation or lack of it and on the extent of involvement of state officials and the degree to which they enforce the law. These factors reflect the fact that the underground economy is at once a political and an economic phenomenon. The researcher must therefore investigate the political context of the forms of exchange being studied simultaneously with efforts to gain acceptance. 
Anthropological methods are particularly suited to such research: because of their reliance on establishing trust and rapport, they are particularly useful for investigating activities that may be clandestine; their holistic emphasis calls for examination of the political and other contexts of any economic phenomenon; and they are adapted to studying societies lacking statistics in which economic exchange commonly takes place in the context of personal relationships. In recent years, the classic techniques of anthropological research, emphasizing community studies and lengthy immersion in local life to gain acceptance, have adapted to the changing interests of anthropologists as they move beyond their early focus on small-scale communities, rather isolated in time and space, to investigate also the regional, national and global context of local phenomena (e.g. Roseberry 1983). Collecting data over space and time is likewise a requirement for research on traders. Since traders are mobile, researchers have to find informants and get their trust not just in a single community but in much wider contexts: in frontier zones and their markets, in dispersed networks extending over long distances and between countries and in the urban immigrant populations on which traders depend as they move around. The trade flows change rapidly in response to changing markets and to political opportunities or constraints. Such complexity is best addressed by a multifaceted approach to collecting data, drawing on a variety of research methods.

A primary technique is that of "snowball sampling" among networks based on kinship, friendship and other ties, using interview schedules that employ open-ended questions to minimize intervention from the researchers (Cornelius 1982, 393-95). A critically important method for doing such research is to work in collaboration with local people who have the contacts to enable them to establish the confidence of informants, as well as in-depth background knowledge of the political context. Researchers need to collaborate with scholars or experts local to the area of the research and to use local people as research assistants. They also need to enlist the active participation in the research of someone from the milieu of the traders, a collaboration that is essential for entry to networks and to make possible participant observation of any kind. Such help is also essential for the variety of language skills needed, since to be able to speak, or to have a professional assistant who can speak, the same language as an informant is a vital factor in gaining trust.

Collaboration of this sort has been featured in several existing studies of unrecorded trade. ${ }^{5}$ In their research on frontier trade in Benin over a period of 15 years, Igue and Soule of the National University of Benin used a multi-disciplinary approach with the assistance of students from the university, and of researchers and teachers from the University of Benin in Togo, from the Universities of Niamey in Niger 
and Ife in Nigeria. Since 1984, they have further experimented with this method in collaboration with INRA, an international group of economists at Montpellier, in a study of frontier trade throughout West Africa in relation to food supplies. This research program is still in progress, and is supported by the Ministry of Cooperation and Development and the Club du Sahel of OECD (Igue and Soule 1992). Herrera, from ORSTOM in Paris, did research on trans-frontier trade between Cameroon and Nigeria in collaboration with three Cameroonians: an agro-economist who had researched such trade in North Cameroon, a statistician from the government bureau of statistics and a geographer from the University of Yaoundé who had researched the manufacturing industry in Douala. For their market studies in Douala, Kumba and Bamenda, they were joined by two more local statisticians. They did the research with supervised teams of five researchers who were locals (Herrera 1992a). In a study of trade across Zaïre's borders, MacGaffey collaborated with Zaïrian anthropologists, all of whom had previously done research on underground economy activities. For the project, Makwala, a professor at the National University of Zaire in Kinshasa, did a market study in his home area of Bas Zaïre, using seven research assistants who spoke the local language and had a minimum of six years of secondary education, to gather data on prices under a university student supervisor, and three additional assistants to travel with traders on trucks as participant observers. Vwakyanakazi, a professor at the University of Zaïre in Lubumbashi, returned to his home region of Kivu to gather data by using his many contacts. Rukarangira collected data on smuggling and fraudulent trade across the Zairre-Zambia border of Shaba, using his privileged access to trader networks for participant observation. His account of his research is a good example of the physical endurance that may be needed for participant observation in this kind of research (MacGaffey, Vwakyanakazi, Rukarangina, Schoepf, Makwala, and Walu 1991). More recently, MacGaffey and Bazenguissa (originally from Brazzaville) have done collaborative research in Paris on Central Africans who trade between Kinshasa, Brazzaville and Paris and other cities in Europe, the Far East and the US. Many of the informants in this study were living in Paris without residence papers and engaged in a variety of activities outside the law. To enter their milieu, the researchers had an assistant who was himself living in the city without papers, to make contacts and introductions and certify the trustworthiness of the two anthropologists (Bazenguissa and MacGaffey 1995; MacGaffey and Bazenguissa 1995).

How is it possible to get the time depth in research on unrecorded trade that can document the flexibility and rapid response and adaptation by traders to changing circumstances? Collecting life histories and case studies of individuals, that record their activities 
through time and space, is an extraordinarily rich source of documentation for such questions. Given the difficulty of research on unrecorded trade, this is a particularly useful technique. It is not possible in such research to get large numbers of informants and it takes considerable time and effort to establish trust and confidence with any particular individual. Once this is gained, however, there is good potential for collecting a great deal of detailed information on, for example, traders' motivations, how they enter and organize their trade, the decisions they make and the reasons for them, how they cope with the vicissitudes of changing political and economic circumstances, their history of profits and losses and how they invest, what the networks are based on and how they are activated and operate. Case histories have been successfully and extensively used for research on unrecorded trade (MacGaffey and Bazenguissa forthcoming; Ebin 1993, 1992; Lambert 1993; Labazée 1993; Rukarangira and Schoepf 1991; Schoepf and Walu 1991). In the course of interviews to record such histories, the researcher elicits the same categories of information from each informant. Data collection is thus systematized and patterns emerge. Even if the numbers of histories collected is not large, the extraordinary richness and interest of the data they may contain can make up in quality for the lack of quantity.

An important method for studying the flows of unrecorded trade and the commodities that are traded is through market studies. These should involve: a survey of the origins of products in markets on both sides of a border, and whether or not they are being re-exported; 6 comparison of prices; estimates of the volume of products; investigation of the networks and organization of the market traders; and gathering information on whether goods are actually smuggled or are in some way fraudulently taken across borders (Herrera 1992a). Sometimes special markets are set up to sell or barter smuggled commodities: for example in Zaïre, the markets in border towns on the frontiers with the Sudan and Uganda where vehicles and other goods are bartered directly for gold, coffee or ivory (Vwakyanakazi 1991, 53-54); the Kenia marketplace in Lubumbashi stocked with goods illegally exported from Zambia; and the Mariano market which existed for several years from 1988 in Kinshasa to sell goods brought by traders from Angola, and which was competitive with the supermarkets as a source of imported goods. Igue and Soule $(1992,85,89-92)$ list frontier markets in Benin in which unrecorded trade dominates, and others which are entrepots specializing in particular commodities. Stary (1994) has studied the markets that have appeared since the mid-seventies on the GhanaCôte d'Ivoire frontier which supply Ghanaian communities with goods from Ivoirian cities and in turn sell them food; much of this commerce crosses the frontier clandestinely. 
Market studies need to be accompanied by extensive interviewing of ministers and local government officials, customs authorities, business-owners, company and parastatal directors and others in charge of official commerce, as well as with those who use the market. In addition to providing another source of data on various aspects of the trade, interviews with people in charge of the official economy reveal the political context which conditions underground activity.

Although underground trade is unrecorded, investigation of archival and published documentation is still an important and useful research method for identifying different forms of the trade. It is as useful for information on the micro as it is on the macro aspects of unrecorded trade shown above. Local newspapers are a valuable source of information. In the situation of political and economic crisis in which most Africans have long been struggling, almost everybody has to supplement their derisory wages and salaries with underground economic activities of some kind. There is great awareness of and interest in the many forms they take: details on them constitute highly relevant and interesting news for the local readership. Reports on such activities may thus be quite frequent and sometimes take the form of high quality investigative reporting. ${ }^{7}$ As well as supplying examples and details of trading activities, local newspapers sometimes give a long-term perspective on political events, on underground economic activities and on the relation between the two, that the temporarily resident researcher has difficulty in obtaining in any other way.

At the local level also, the economic effects of large scale smuggling and fraudulent export are significant enough that government economic offices attempt to compile information and data on them in their annual reports and other documents. Any quantitative estimates are likely to be highly unreliable and need to be cross-checked with other sources, but such documents have their uses when put together with other data. While statistics on the flows of clandestine trade are obviously lacking, statistics on official economic activity, on export and trade, production, sale and transport, can yield a wealth of relatively precise information on unofficial trade flows. Igue and Soule $(1992,15)$ point out that comparison of statistics such as those from the Ministry of Commerce, the Bureau of Statistics, the Customs and Tax Offices and the Central Bank often show irregularities that reveal the extent of clandestine flows of goods. Herrera, in his research on the unrecorded trade of cattle from Nigeria to Cameroon, found that the cattle permit register of the livestock service showed the Nigerian provenance of cattle coming to Bamenda, while the statistical department of the same service ignored this trans-border flow and listed the origin of all cattle as Cameroon (Herrera 1992b).

There are considerable ethical problems in research on activities outside the law, with the possibility that both researcher and, 
particularly, informant, may be placed in jeopardy. A major problem is how to ensure the protection of informants. Great caution is required until the researcher knows for sure that informants are not being jeopardized in any way, which can slow down and sometimes preclude entirely research on some topics. There is also the problem that research is inevitably often extremely arduous, frustrating and difficult and may be downright dangerous: some investigations may precipitate violent suspicious reaction as researchers find themselves at the interface between the authorities and the people evading law enforcement, or between racial, ethnic and other groups in potentially violent conflict and competition in their economic activities. A warning to take great care, for themselves and for their informants, is sounded here to all potential researchers.

Another problem that is immediately obvious is how representative and comprehensive data can be when collected in these difficult research conditions and how they can be corroborated. The multifaceted approach to collecting data outlined here and the crosschecking it involves present a partial solution to such a problem: data collected by one method may be corroborated by those collected by another, and gaps in information may be filled. But for some forms of underground trade, information is inevitably incomplete; in such cases, something is better than nothing. It is a research process which resembles nothing so much as fitting together the pieces of a jigsaw puzzle. It is very different from the conventional techniques of survey research and administration of questionnaires to a randomly sampled population, or the careful inventory of community economic activities observed and participated in by a researcher. But the research methods useful for studying unofficial economic activity outlined above are likely to become more useful than these conventional ones as globalization of economies around the world increases. In this process, as exchange is regulated by international organizations and multinational corporations, which themselves often operate through forms of personal networks, economies of nation-states and their component local units and national economic statistics become less significant than these various forms of network. Research on underground trade and other networks, on how they are organized and who participates in them, has become a pressing necessity; much more of it is needed.

\section{Some Suggestions for New Directions in Research on Unrecorded Trade}

Important topics for more research on unrecorded trade exist not only on the issues discussed so far but also on the perceptions of people engaging in the trade and on the cultural image of the trader (Klein 1994, 660-64). For example, how do people themselves conceptualize 
what they are doing? What are their models? What are their perceptions of the controls they are evading or exploiting? That people do differentiate trade and other activities of the second economy from official economic transactions is evident in the terms that exist for the second economy: "kalabule" in Ghana, "l'économie de débrouillardise' or "système D" in Zaire, "magendo" in Uganda, "ulanguzi" in Tanzania, and "candonga" in Angola. But we do not know very much about what people actually think about these activities or the people who engage in them.

Clearly one perception is that engaging in unrecorded trade is a means of survival when the political and economic situation precludes other possibilities. Marketing infrastructure in some countries has so deteriorated that small farmers can sell their goods only to unlicensed traders, or can get prices that will enable them to purchase the goods they need only by smuggling their produce across borders. For the same reason, they may resort to bartering the commodities they produce directly for manufactured goods which are illegally imported. For those with access to the commodities of the more lucrative forms of unrecorded trade, this form of activity offers a means to get rich to a degree that is impossible in the official wage and salary sector. But more information is needed on how people in such circumstances view the illegal aspect of their activities. How widespread is the perception that these activities are perceived as resistance to oppression of various kinds? One study speaks of the emergence of a "conscience de solidarité" originating in linguistic and cultural affinities which becomes a mode of defiance against state imposed constraints (Igue and Soule 1992, 97, 99). Some researchers find the idea of resistance to be very explicit when people talk about smuggling (Vwakyanakazi 1982, 339-40). In Uganda, magendo is simply a perfectly permissible form of economic activity for getting around regulations perceived as meddling and interfering by means of which the state bourgeoisie levies its tithes (Prunier 1983, 53). Some Africans engaged in clandestine activities in Europe feel that, since Europe plundered Africa in the colonial period, they are justified now in turn in seeking their share of booty. Also, how do people categorize and think about the different commodities of unrecorded trade? Among Central African traders in Paris, it was clear that some simply considered drugs as just another, and particularly lucrative, commodity, while others set them in a category apart and avoided dealing in them and also in high value stolen goods because of the risk of landing in jail.

Research on cross-border trade in foodstuffs and consumer goods is less dangerously illegal for researchers and perhaps more feasible for investigation than drugs or precious metals. Studies include an extensive body of material from the Club du Sahel on the cereal trade in West Africa (Egg and Igue 1993; Hibou 1990), Herrera's investigation 
of the cattle trade between Nigeria and Cameroon (Herrera 1992b), and Vwakyanakazi's work on the smuggling of consumer goods from East Africa to Zaïre (Vwakyanakazi 1982, 1991). Much more research needs to be done on the flows of vast quantities of these and other commodities across African borders.

However, there is also cogent evidence that the major operators in unofficial trade, including inter-continental trade, are directly connected to holders of political office and that their ability to trade on a large scale depends on the quality of their political contacts (Hibou 1996, esp. pp. 141-70). The relationship between major traders enjoying top-level political contacts, and the small-scale traders operating on smaller margins, is a subject in need of further study.

What changes in social structure result from unrecorded trade? Does it contribute to local economic development? Some very interesting findings on this topic are reported, for example, in Uganda and Zaïre. Nabuguzi's research on the rice trade in Busoga, Uganda, shows that small farmers marketing their rice through unofficial trade circuits within and beyond Uganda's borders invest their surplus in local enterprise. Local power is shifting from the clientelistic agents of the state to a new wealthy class based on the rice trade (Nabuguzi 1992, ch. 8). Vwakyanakazi's investigation of artisanal gold mining and the gold trade in North Kivu, Zaïre, shows demand created by the mining camps is stimulating local agricultural production, the creation of informal enterprises (such as shops, bars, markets and dispensaries), and the repopulation of local villages (Vwakyanakazi 1992, 384-87). Some of the people who engage in clandestine trade are creating their own value and status system in which they dispense the wealth they earn (Bazenguissa and MacGaffey 1995; MacGaffey and Bazenguissa 1995); how widespread is this phenomenon? Data on all these topics are just beginning to appear; all constitute important directions in which to develop new research.

\section{New Forms of Unofficial Trade and New Kinds of Traders}

International trade in Africa, and inter-continental trade particularly, occupies a crucial strategic position chiefly because of the scarcity of the foreign exchange which is necessary to import manufactured goods and which can play a vital role in the construction of a political power-base. Government ministers and officials regulate access to hard currency either by their control of the state, or by going into business themselves or through nominees including members of their own family, or indirectly, by forming alliances with traders. The interplay of the resulting trade and clientelist networks is an ingredient in most successful political careers in Africa. 
In the 1960s and 1970s, when import substitution policies and overvalued currencies were commonplace, political careers and commercial fortunes could be made by the allocation of import licenses and by unofficial or illicit currency deals. The situation has changed since the adoption of structural adjustment policies by most African governments. Nevertheless politicians, civil servants and traders still cooperate to structure international trade to their advantage, and the changing patterns of unofficial trans-border transactions are best interpreted in this context.

According to the liberal economic theories which have acquired the status of orthodoxy in recent years, it is not, generally speaking, the task of national governments to organize markets. Rather, the essential economic task of governments is seen as that of providing the infrastructure and encouraging the macro-economic climate which will enable markets to operate freely and efficiently. This involves ensuring the existence of a reliable currency which will serve as a medium of exchange in market transactions and which can be freely exchanged for other currencies. When a transaction takes place, or is planned, partly or wholly outside the national territory, traders in Africa are likely to want to trade their local money for a "hard" currency such as US dollars. An overvalued currency will thus be forced by the hidden hand of the market to adjust to the real exchange rate at which traders are prepared to do business. For example, in the case of West Africa, the devaluation of the CFA franc in January 1994 was inevitable (and in liberal theory desirable) as soon as it became clear that traders, particularly those operating with a more realistically valued naira in the large and influential Nigerian market, were buying overvalued CFA francs on a large scale in order to have an internationally negotiable currency for their import-export businesses.

The free trade and free foreign exchange policies which have been widely implemented in Africa since the early 1980s encroach on powerful vested interests. As long as differential currency rates and pricing regimes exist, national frontiers in Africa (notably that between the Nigerian naira zone and the neighboring CFA zone with its fixed exchange rate with the French franc) may themselves be considered a resource. A product transferred from one side to another of such a border can gain or lose value as a result of the transfer. The frontier, the point of import and export, is the critical factor in most smuggling operations. (But not all, since some smuggling is designed to escape domestic market or production controls, and not only international ones). Clearly, a trader who is able to import goods to Africa without paying any of the taxes or other payments officially required or who can manipulate exchange rates better than his or her competitors will have an advantage over other operators in the same market. Importation of 
goods which do not conform to official marketing requirements will not appear in national statistics.

Import-export business of this type is highly sought after by traders in Africa who see it as one of the most profitable options open to them. The supply of imported goods alone is often not conducive to the establishment of a sustainable, profit-making enterprise-in spite of the high profits to be made on some imported goods-since payment by customers in much of the continent will be in the form of a national currency. The latter may be of little or no international value and will not help the importer to buy trade goods at source in the industrial world or to settle his or her international obligations. Even currencies which are theoretically tradable are often so weak as to have no international demand. A trader who possesses no foreign exchange will be unable to finance new imports from the developed world and thus begin a new cycle of transactions.

For these reasons importers to Africa generally seek also to export. It is the combination of the two activities, importing and exporting, which permits a successful trader to manipulate "soft" and "hard" currencies in order to achieve a significant level of profit and to obtain the straddling position which is generally crucial to success (Azam and Besley 1991; May 1985). Here, as in some other respects, we may distinguish between intercontinental and regional traders in Africa. A trader in intercontinental markets will have vital need of an internationally negotiable "hard" currency, normally dollars, whereas a trader in African regional markets may handle mostly local currencies. Thus, a trader who specializes in selling locally-produced foodstuff in East African markets may hold, and perform transactions in, Kenyan, Ugandan and Tanzanian shillings, all of which are negotiable in East Africa but have little or no value elsewhere. In all cases, however, the aim of an exporter, as of an importer, is to incur the lowest possible costs, evading tariffs and other payments if possible.

Although such high-bulk, low-value products as grains and other food staples may be successfully traded between African countries, since the overhead costs are relatively low, they cannot generally be traded with the industrialized world. Many African cash crops have proved in recent years to be uncompetitive in the major intercontinental markets, with exceptions such as horticultural produce or other products for "niche" markets (Dijkstra and Magori 1995). African countries have a comparative advantage in very few fields and those products which can be exported for hard currency-in other words which are attractive to buyers from the industrialized world-tend to be those of internationally recognized value which exist naturally, such as ivory and other animal products, diamonds or other gems, and gold, rather than goods which require significant capital investment in their production. Diamonds, gold and other valuable minerals can be 
found with virtually no investment other than labor. Stringent controls often exist on their extraction and sale, but there is abundant evidence that in countries such as Angola, Zaïre, Sierra Leone and Liberia which have important reserves of these and other precious minerals, governments are incapable of enforcing such laws. Indeed, ministers and even heads of state may use the resources at their disposal to organize smuggling rings for their own profit at the expense of the state. The diamond- or gold-diggers themselves receive only a small fraction of the international value of any gems they are lucky enough to find, just as the poacher who kills an elephant or rhinoceros will receive only a small proportion of the international value of a rhino horn or a tusk which he sells.

An interesting and important exception to these remarks on the absence of capital-intensive production for export markets is in respect to oil, which can be produced and marketed only with a high degree of technical knowledge and major investment. This rules it out as an object of artisanal exploitation. Nevertheless, such is the importance of oil to the industrialized economies, and so substantial are the profits to be made from its exploitation, that oil companies are willing to risk investment in production in Africa. In oil-producing countries of Africa traders with access to the right government officials can earn a fortune from the manipulation of oil contracts without themselves making any investment or having any degree of technical knowledge of the product. So crucial is the interface between the domestic and the intercontinental economic spheres that we may state that in general, wherever in Africa there exist products which can find a market in the industrial world and can thus be sold for hard currency, it tends to be the middlemen who make the big profits, in effect deriving a reward for the effort they have invested in building up a position of access to international markets and in defending themselves against commercial rivals who may not hesitate to use coercive methods to secure an advantage. In short, a successful exporter from Africa requires not only the usual range of commercial skills and capital, but also political, and often also physical, protection. This in turn requires a major investment of money and time and the cultivation of appropriate political and social contacts.

It is of course quite possible for a trader or a company to specialize in the export of African products for sale on world markets without reinvesting the profits largely in ensuring future production (such as by digging a new oil well) or by importing goods for sale in African markets. This is the position of, for example, the diamond giant De Beers, which buys diamonds from various parts of Africa and sells them for hard currency in international markets, thus generating massive hard currency profits. De Beers does invest in new diamond mines, but it also uses a substantial part of its profits to maintain a vast 
cash surplus which is necessary for the stabilization of the diamond market. Most individual traders or smaller family businesses operating in Africa do not have the option of holding the hard currency derived from their exports over a long period. They are obliged to reinvest their profits to a large extent both in political pay-offs and in imports with which they can generate local currency profits, because access to exportable goods in Africa is generally not open to all comers but is dependent on repeated participation in a political-commercial trading system, other than for the lucky person who manages to make a one-off export transaction of sufficient value to provide the start-up capital for some other means of subsistence. The sale of export goods in international markets for hard currency can then finance the imports of consumer goods or other goods which will complete the cycle.

Studies of African traders suggest that different categories of people take part in these commercial networks (Ellis and Fauré 1995). In the first place, we may distinguish between regional African trade, which can be a source of considerable profit for grain merchants or cattle merchants for example, and intercontinental trade. In both cases, it seems that there are "target marketeers," occasional traders who make a small number of trips to obtain money, either for some specific purpose or with a view to breaking into full-time trade. The greater the distance covered by the trade, the more likely is a trader to carry a high-value product which is destined ultimately for markets outside Africa and which costs little to transport. For example, a considerable proportion of the ivory-smugglers arrested in South Africa are not specialist ivory traders, but are individuals from Central Africa who travel to Johannesburg overland with a view to buying an imported or manufactured product, such as electrical goods, for resale at home. Since the Zambian kwacha or the Zaïrian zaïre, for example, have no value in South Africa, people from Central Africa wishing to break into this trade need to equip themselves with a product such as ivory which is obtainable in Central Africa but which also has an international value. ${ }^{8}$ Similarly, people who are not full-time professional traders may try their hand at import-export if the opportunity arises, for example making use of a trip overseas to do some business on the side without ever aspiring to become full-time traders. Favorite forms of such transactions include the export of second-hand cars and secondhand clothes from Europe to Africa. Civil servants, officials of nongovernmental organizations, consultants and others from Africa may be invited to the industrialized world in connection with a conference or some official business. They will often be tempted to use this opportunity--and the vital hard currency daily allowance or honorarium-to perform a business transaction which can result in a useful windfall profit, without necessarily wishing to go full-time into the import-export business. 
Second, there are specialized professional traders. These certainly include whole communities specialized in regional trade over many centuries, such as the Dyula merchants of West Africa, who traditionally buy and sell across borders. In more recent times some have become lorry-drivers or long-distance taxi-drivers, trading as a sideline when the opportunity arises. Individuals who succeed in such local or regional trade may eventually have the option of breaking into inter-continental trade. In the case of inter-continental trade, traders are generally not vertically integrated in the sense that they do not exert any direct control over the producers of the products which they market. However, so organized (and highly competitive) is the trade in gems, gold, ivory and other high-value exports that major operators may need to be members or associates of an organization of a quasipolitical or quasi-criminal nature. The exploitation of these products requires the exercise or threat of physical force, such as that exercised by rival armies in controlling the diamond fields of north-eastern Angola or the various warlords who influence import-export trade in Zaïre (De Boeck forthcoming). In some cases powerful warlords may themselves personally negotiate import-export contracts, like Charles Taylor in Liberia (Reno 1993). In other cases, political figures-a Mobutu or a Savimbi-in effect head organizations which bear a resemblance both to states and to business firms, having middlemanagers who may negotiate contracts on their behalf and with whom profits are shared. Import-export traders who are of foreign origin, such as Indian, Pakistani, Lebanese or Greek traders, play an important role in many such systems. They have the international contacts which give them good access to markets and the local contacts which are essential to work the system. They require the services of local politicians or warlords, however, both to protect themselves against robbery and to stabilize their labor force. Even some highly formal firms, such as the British company Lonrho, operate in a similar manner in some respects (S. Cronje, Ling, and G. Cronje 1976).

In recent years some important import-export networks have discovered in the drug trade particularly a major new area of business. Although different groups have taken an interest in this line, Nigerian syndicates in particular, possibly operating with protection at a high level, have carved out a major market share. Nigerian elites have both the capital necessary to finance the business and access to major international trading and banking networks. Nigerian traders, working either alone or in family syndicates or for one of the major importexport groups, buy heroin and cocaine at source, transport it to Nigeria (where, with suitable political protection, import is not a problem) and then re-export it to the consumer markets. In recent times they have increasingly used South Africa as a staging-post (Baynham 1995). "During the past six months," reported the anti-apartheid activist 
Dr Beyers Naudé in September 1994, "South Africa has become a transit country for trade in heroine [sic] and cocaine with European countries and for the Americas." South African Deputy Safety and Security Minister Joe Matthews has estimated that more than 100 drug syndicates are operating in South Africa (Naudé and Kistner 1994).

African traders, whether living in Africa itself or in the industrialized world, often form themselves into business associations in order to maximize their advantages in import-export business. Broadly speaking, these advantages are as follows: first, in cases where a high-value product is to be found in Africa, it ensures that members of a distinct social group, generally of kin, rather than outsiders have direct access to the very high mark-ups to be derived from the exploitation of the product. A humble diamond-digger in Angola or Sierra Leone leads a poor existence, and may make only a relatively small sum even if he has the luck to make a find. Such workings are generally subject to control by an armed group which will ensure that it takes possession of any minerals found, or at least takes a good cut of the profit mark-up in the event that marketing is the province of Lebanese, Indians, Europeans or other aliens (Richards 1995). Second, in cases where a trade has a higher degree of vertical integration, such as the marketing of drugs by Nigerians in some US cities, the existence of a diaspora can be turned into a commercial advantage. Third, an individual who wishes to become a full-time trader, rather than just the beneficiary of a one-off profit, will probably need to secure access to some item which can be exported from Africa as well as to a source of imports. This in turn may require negotiating a relationship with one of the big import-export associations, in effect giving up a share of profits in exchange for access to gems, works of art, gold or immunity from prosecution for the smuggling of drugs. The number of low-level couriers convicted of narcotics smuggling in Nigeria, while very senior figures are widely known for their involvement in the trade, is an indication of the risks run by individuals who attempt to build up such a business without negotiating an agreement with one of the established firms.

In many respects, the system outlined here bears a resemblance to the patterns of long-distance trade described by historians of precolonial Africa (Curtin 1984; Lovejoy 1986). The models of long-distance trade developed by historians of pre-colonial Africa may be usefully applied to the study of comparable modern phenomena (cf. Bank 1990). Nevertheless it would appear that the organization of modern longdistance trade differs in important respects from that of its pre-colonial equivalent. Perhaps most crucially, the growth of modern cities and transport, compared to the caravans of old, represents a vast restructuring of African markets and especially of the articulation between local and international markets. Although historians have 
long ceased to believe in the existence of widespread subsistence societies in pre-colonial Africa, low levels of income and the dependence on pre-industrial forms of transport did tend to impose in the past a distinction between local and long-distance trade, the latter based on high-value and relatively scarce goods, such as iron and salt. Today, the relationship between long-distance trade, local trade and household patterns of production and consumption remains a matter in need of further research. ${ }^{9}$ It is particularly striking that the growth of the new forms of long-distance trade is both a result of the crisis of many African states (since state apparatuses are no longer strong enough to exert control) and a cause (since smuggling deprives states of revenue and may be accompanied by forms of privatized violence).

Some writers on the pre-colonial systems of long-distance trade have suggested that control of long-distance trade was closely connected with political power in an African mode of production (Coquery-Vidrovitch 1969). This too is a theory developed by historians to account for certain developments in pre-colonial Africa, but which may well be usefully applied to current situations. The failure of industrialization in most of Africa, and the increasing evidence of the relative failure of attempts to regenerate the production of export crops in order to earn foreign exchange on world markets, has produced a situation where the export of high-value minerals or other commodities or the trading of products from other countries in third-country markets are increasingly important as sources of foreign exchange. The maintenance of domestic political power depends upon control of, or access to, the profits of such trade. It may throw light on the nature of import-export systems and of their political and social aspects, including the increasing tendency for power-brokers in Africa to use force to protect their access to longdistance trade channels.

\section{Notes}

*We are grateful to Béatrice Hibou and Bogumil Jewsiewicki, as well as to a number of anonymous reviewers, for comments on an earlier draft of this article.

1. In Zaïre, for example, a 1973 law gave the National Ivory Bureau the monopoly on sales. Officials became heavily involved in smuggling, however, and by 1976 an estimated 90 percent of Zaïre's ivory was smuggled. All export was banned in 1978 and all sales in 1979. Since then, Zaïre's elephant population has been heavily poached.

2. Parker was commissioned by the US Fish and Wildlife Service in the 1970s to write a report on the history of the ivory trade, and was able to travel extensively both in and outside Africa, adding to his existing knowledge of the subject. The resulting study was never published (Parker 1979) although Parker later published some of the material elsewhere (Parker and Amin 1983, 85-97, 151-75) and his figures have also been used, in combination with data from similar sources, in other work (Barbier, Burgess, Swanson, and Pearce 1990). 
3. Statistics on ivory movements and occasional monographs on aspects of the trade are published in conservationist reviews such as Traffic International Bulletin (Cambridge, bi-monthly, 1979- ) and Swara (Nairobi), the journal of the East African Wildlife Society.

4. e.g. United States Department of State $(1995,435)$, which describes Nigeria as "a major transit country for Asian heroin and Latin American cocaine destined for the international market." Fottorino (1991) publishes material from official sources in an annexe. Alain Labrousse, author of a book on the drug trade, is also the publisher of a newsletter, La dépêche internationale des drogues, which has appeared since June 1991.

5. Such collaboration builds interestingly on Gudeman and Rivera's work in Columbia (Gudeman and Rivera 1990).

6. The West African states of Benin, Togo and Gambia have been called entrepot states because of the dominance of this activity (Igue and Soule 1992).

7. Gauthier de Villers' study of Zaire in 1990-1991, as seen through press accounts, devotes a whole chapter to newspaper articles on second economy activities (de Villers 1992, ch. 2).

8. Stephen Ellis, interviews with officials of South African Police Endangered Species Protection Unit, Pretoria, September 1993.

9. For a survey of literature and of the main theoretical questions concerning the relations between household and community, see Guyer 1981.

\section{References}

Alessandrini, Sergio and Bruno Dallago (eds.) 1987. The Unofficial Economy. Aldershot: Gower.

Azam, J. P. and T. Besley. 1991. “General Equilibrium with Parallel Markets for Goods and Foreign Exchange: Theory and Application to Ghana,"World Development 17, 12:19211989.

Bank, Leslie. 1990. “The Making of the Qwaqwa 'Mafia'? Patronage and Protection in the Migrant Taxi Business," African Studies 49, i: 71-93.

Barbier, Edward, Joanne Burgess, Timothy Swanson and David Pearce. 1990. Elephants, Economics and Ivory. London: Earthscan.

Baynham, Simon. 1995. "The Fourth Horseman of the Apocalypse: Drug Trafficking in Africa," Africa Insight 25, 3:149-153.

Bazenguissa, Rémy and Janet MacGaffey. 1995. "Vivre et briller: à Paris, des jeunes Congolais et Zairois en marge de la légalité économique," Politique Africaine 57: 124-33.

Cesoni, Maria Luisa. 1992. "Les routes des drogues: explorations en Afrique subsaharienne. Etat des lieux pour une approche critique," Revue Tiers Monde 33, no.131: 645-71.

Coquery-Vidrovitch, Catherine. 1969. "Recherches sur une mode de production africaine," Pensée 144: 3-20.

Cornelius, Wayne A. 1982. "Interviewing Undocumented Immigrants: Methodological Reflections Based on Fieldwork in Mexico and the US," International Migration Review 16: $378-411$.

Cronje, S., M. Ling and G. Cronje. 1976. Lonrho: Portrait of a Multinational. Harmondsworth: Julian Friedmann and Penguin.

Curtin, Philip. 1984. Cross-Cultural Trade in World History. Cambridge: Cambridge University Press.

De Boeck, Filip. Forthcoming. "The Zaïrian Crisis: Local and Global Perspectives," in T. O. Ranger and R.P. Werbner (eds.), Postcolonial Identities in Africa. London: Zed.

De Villers, Gauthier. 1992. Zaire, années 90. Zaire 1990-1991: faits et dits de la société d'après le regard de la presse. Brussels: CEDAF.

Dijkstra, T. and T.D. Magori. 1995. "Flowers and French Beans from Kenya: a Story of Export Success,"in Stephen Ellis and Yves A. Fauré (eds.) Entreprises et entrepreneurs africains. Paris: Karthala, 435-44.

Douglas-Hamilton, Iain and Oria Douglas-Hamilton. 1992. Battle for the Elephants. London: Doubleday. 
Dupriez, Pierre. 1968. "Les relations économiques extérieures (du Congo)," Indépendance, inflation, développement: l'économie congolaise de 1960 à 1965, 559-724. Kinshasa: IRES, Université Lovanium de Kinshasa. Paris: Mouton.

Ebin, Victoria. 1993. "Les commerçants mourides à Marseille et à New York: regards sur les stratégies d'implantation," in Emmanuel Grégoire and Pascal Labazée (eds.) Grands commerçants d'Afrique de l'Ouest: logiques et pratiques d'un groupe d'hommes d'affaires contemporains. Paris: Karthala, 101-24.

-1992. "A la recherche de nouveaux 'poissons' : stratégies commerciales mourides par temps de crise," Politique Africaine 45:86-99.

Egg, Johnny and John O. Igue. 1993. L'intégration par les marchés dans le sous-espace est: l'impact du Nigéria sur ses voisins immédiats. Club du Sahel-CILSS. Paris: INRA-UNBIRAM.

Ellis, Stephen and Yves-André Fauré (eds.) 1995. Entreprises et entrepreneurs africains. Paris: Karthala.

Fottorino, Eric. 1991. La piste blanche: l'Afrique sous l'emprise de la drogue. Paris: Balland.

Gudeman, Stephen and Alberto Rivera. 1990. Conversations in Columbia. Cambridge: Cambridge University Press.

Guyer, Jane. 1981. "Household and Community in African Studies," African Studies Review 24, ii-iii: 87-137.

Herrera, Javier. 1992a. "Observatoire OCISCA. Impact des politiques différentielles et échanges transfrontaliers Cameroun-Nigeria," Rapport de Mission: Provinces du Littoral, Sud-Ouest, Ouest et Nord-Ouest (29/6/92-5/7/92; 13/7/92-19/7/92). Paris: ORSTOM, mimeo.

1992b. "Bétail, naira et franc CFA:un flux transfrontalier entre Nigéria et Cameroun." Study in the North-West province of Cameroon supported by OCISCA. Paris: ORSTOM, mimeo.

Hibou, Béatrice. 1990. Analyse comparée des politiques de protection et de régulation des marchés céréaliers ouest-africains. Club du Sahel-CILSS. Paris: INRA-UNB-IRAM. 1996. L'Afrique est-elle protectionniste? Les chemins buissonniers de la libéralisation extérieure. Paris: Karthala.

Hugon, Philippe and I. Deblé (eds.) 1982. Vivre et survivre dans les villes africaines. Paris: Presses universitaires de France.

Igue, John O. and Bio G. Soule. 1992. L'État entrepôt au Bénin:commerce informel ou solution à la crise? Paris: Karthala.

Klein, Axel. 1994. "Trapped in the Traffick: Growing Problems of Drug Consumption in Lagos," Journal of Modern African Studies 32, 4:657-77.

Labazée, Pascal. 1993. "Les échanges entre le Mali, le Burkina Faso et le nord de la Côte d'Ivoire," in Emmanuel Grégoire and Pascal Labazée (eds.) Grands commerçants d'Afrique de l'Ouest: logiques et pratiques d'un groupe d'hommes d'affaires contemporains. Paris: Karthala, 125-74.

Lambert, Agnès. 1993. "Les commerçantes maliennes du chemin de fer Dakar-Bamako,"in Emmanuel Grégoire and Pascal Labazée (eds.) Grands commerçants d'Afrique de l'Ouest: logiques et pratiques d'un groupe d'hommes d'affaires contemporains. Paris: Karthala, 37-70

Lovejoy, Paul. 1986. Salt of the Desert Sun. Cambridge: Cambridge University Press.

MacGaffey, Janet, (with Vwakyanakazi Mukohya, Rukarangira wa Nkera, Brooke Grundfest Schoepf, Makwala ma Mavambu Ye Beda and Walu Engundu). 1991. The Real Economy of Zaire: the Contribution of Smuggling and Other Unofficial Activities to National Wealth. London: James Currey.

MacGaffey, Janet and Rémy Bazenguissa. 1995. “Ostentation in a Clandestine Setting: Young Congolese and Zairian Migrants in Nganda Bars in Paris," Mondes en Développement 23, no. 91: 105-11.

. Forthcoming. "The End of the Rainbow: Three Case Studies of Women Traders from Central Africa," in Tamar D. Wilson and Judith E. Marti (eds.)Women in the Informal Sector. New York: SUNY Press.

May, Ernesto. 1985. Exchange Controls and Parallel Market Economies in Sub-Saharan Africa: Focus on Ghana. Washington D.C.: World Bank Staff Working Papers, no. 711.

Nabuguzi, Emmanuel. 1992. "Le Magendo, l'État et la société en Ouganda." Ph.D. Diss., Ecole des Hautes Études en Sciences Sociales, Paris.

Naudé, B. and W. Kistner. 1994. "100 Days in the New South Africa." Braamfontein: Ecumenical Advice Bureau. 
Naudé, B. and W. Kistner. 1994. "100 Days in the New South Africa." Braamfontein: Ecumenical Advice Bureau.

Parker, Ian. 1979. “The Ivory Trade." Washington: US Fish and Wildlife Service, unpublished.

Parker, Ian and Mohamed Amin. 1983. Ivory Crisis. London: Chatto and Windus.

Penouil, M. and J.-P. Lachaud (eds.)1985. Le développement spontané. Les activités informelles en Afrique. Paris: Pedone.

Prunier, Gérard. 1983. "Le Magendo: essai sur quelques aspects marginaux des échanges commerciaux en Afrique Orientale," Politique Africaine 9:53-62.

Reno, William. 1993. "Foreign Firms and the Financing of Charles Taylor's NPFL," Liberian Studies Journal 18, 2:175-87.

Richards, Paul. 1995. "Liberia and Sierra Leone," in O. W. Furley (ed.) Conflict in Africa. London: I.B. Tauris, 13470.

Roseberry, William. 1983. Coffee and Capitalism in the Venezuelan Andes. Austin: Univ. of Texas Press.

Rukarangira wa Nkera and Brooke Grundfest Schoepf. 1991. “Unrecorded Trade in Southeast Shaba and Across Zaire's Southern Borders," in The Real Economy of Zaire, by Janet MacGaffey with Vwakyanakazi Mukohya, Rukarangira wa Nkera, Brooke Grundfest Schoepf, Makwala ma Mavambu Ye Beda and Walu Engundu. London: James Currey, 72-96.

Schoepf, Brooke Grundfest and Walu Engundu. 1991. “Women's Trade and Contributions to Household Budgets in Kinshasa," in The Real Economy of Zaire, by Janet MacGaffey with Vwakyanakazi Mukohya, Rukarangira wa Nkera, Brooke Grundfest Schoepf, Makwala ma Mavambu Ye Beda and Walu Engundu. London: James Currey, 124-151.

Stary, Bruno. 1994. "Les ressources de la frontière: l'exemple Ghana-Côte d' Ivoire." Paper presented at the International Colloquium on Integration and Regionalism, Centre d'études d'Afrique noire, Talence, 27-30 April.

Tanzi, Vito (ed.) 1982. The Underground Economy in the United States and Abroad. Lexington, Mass.: Lexington Books.

Thomas, J.J. 1992. Informal Economic Activity. Ann Arbor: University of Michigan Press.

United States Department of State, Bureau for International Narcotics and Law Enforcement Affairs. 1995. International Narcotics Control Strategy Report, March 1995. Washington D.C.: US Government Printing Office.

Vwakyanakazi, Mukohya. 1982. "African Traders in Butembo, Eastern Zaire (1960-1980): a Case Study of Informal Entrepreneurship in a Cultural Context of Central Africa." Ph.D. Diss., University of Wisconsin, Madison.

1991. "Import and Export in the Second Economy in North Kivu,"in The Real Economy of Zaire, by Janet MacGaffey, with Vwakyanakazi Mukohya, Rukarangira wa Nkera, Brooke Grundfest Schoepf, Makwala ma Mavambu Ye Beda, Walu Engundu 43-71. London: James Currey.

1992. "Creuseurs d'or et crise socio-économique au Nord-Kivu en République du Zaire," Africa (Roma) 3:375-91. 